\title{
Iridoids from Globularia dumulosa
}

Hasan Kirmizibekmez ${ }^{\mathrm{a}}$, Pinar Akbay ${ }^{\mathrm{b}}$, Otto Sticher ${ }^{\mathrm{b}}$, and İhsan Çalış,

a Department of Pharmacognosy, Faculty of Pharmacy, Hacettepe University,

TR-06100 Ankara, Turkey. Fax: +90-3 12-3114777. E-mail: icalis@hacettepe.edu.tr

b Department of Applied BioSciences, Institute of Pharmaceutical Sciences, Swiss Federal Institute of Technology (ETH) Zürich, Winterthurerstr. 190, CH-8057 Zürich, Switzerland

* Author for correspondence and reprint requests

Z. Naturforsch. 58c, 181-186 (2003); received October 15/October 31, 2002

Two new iridoids, 10-O-benzoylglobularigenin (1) and dumuloside (2) were isolated from the aerial parts of Globularia dumulosa together with seven known iridoid glucosides, davisioside (3), aucubin (4), melampyroside (5), catalpol (6), 10-O-benzoylcatalpol (7), alpinoside (8) and deacetylalpinoside (9). Three phenylethanoid glycosides, verbascoside, decaffeoylverbascoside, leucosceptoside $\mathrm{A}$ and three flavone glucosides, pectolinarigenin $7-O-\beta-\mathrm{D}-$ glucopyranoside, nepetin 7-O- $\beta$-D-glucopyranoside, demethoxycentaureidin 7- $O$ - $\beta$-D-glucopyranoside were also isolated and characterized. The structure elucidation of the isolated compounds was performed by spectroscopic (UV, IR, HR-MALDIMS, 1D- and 2D NMR) methods.

Key words: Globularia dumulosa, Iridoids, Phenylethanoid Glycosides, Flavone Glycosides

\section{Introduction}

In the flora of Turkey, the genus Globularia (Globulariaceae) is represented by nine species (Edmondson, 1982; Duman, 2001). In Anatolian folk medicine, G. alypum is used as diuretic, laxative, carminative and tonic (Baytop, 1984), whereas $G$. trichosantha is utilized for the treatment of hemorrhoids (Sezik et al., 1991). Our previous studies have resulted in the isolation of phenylethanoid and iridoid glycosides from $G$. trichosantha (Calis et al., 1999, 2001) and G. davisiana (Calis et al., 2002a) and sugar esters along with iridoid and phenylethanoid glycosides from $G$. orientalis (Calis et al., 2002b). In the course of an investigation of Globularia species growing in Turkey, we have now investigated an endemic species, G. dumulosa O. Schwarz. In this paper we report the isolation and structure elucidation of two new iridoids, 10-O-benzoylglobularigenin (1) and dumuloside (2) obtained from the aerial parts of $G$. dumulosa.

\section{Material and Methods}

\section{General experimental procedures}

Optical rotations were measured on a Rudolph autopol IV Polarimeter using a sodium lamp operating at $589 \mathrm{~nm}$. UV spectra were recorded on a
Shimadzu UV-160A spectrophotometer. IR spectra $(\mathrm{KBr})$ were measured on a Perkin Elmer 2000 FT-IR spectrometer. A Bruker AMX 300 instrument $\left(300 \mathrm{MHz}\right.$ for ${ }^{1} \mathrm{H}$ and $75.5 \mathrm{MHz}$ for ${ }^{13} \mathrm{C}$ ) with XWIN NMR software package was used to acquire NMR data. Positive mode HR-MALDIMS were recorded on a Ionspec-Ultima-FTMS spectrometer, 2,5-dihydroxybenzoic acid (DHB) as matrix. TLC analyses were carried on silica gel $60 \mathrm{~F}_{254}$ precoated plates (Merck, Darmstadt); detection by $1 \%$ vanillin $/ \mathrm{H}_{2} \mathrm{SO}_{4}$. For medium-pressure liquid chromatographic separations, a Lewa M5 pump, a LKB 17.000 Minirac fraction collector, a Rheodyne injector, and a Büchi column (column dimensions $2.6 \times 46 \mathrm{~cm}$, and $1.8 \times 35 \mathrm{~cm})$ were used. Silica gel 60 (0.063-0.200 mm; Merck, Darmstadt) was utilized for open column chromatography (CC) and vacuum liquid chromatography (VLC). LiChroprep C-18 (Merck) material was used for MPLC and VLC. Sephadex LH-20 (Fluka) was also used for further separations.

\section{Plant material}

Globularia dumulosa O. Schwarz. (Globulariaceae) was collected from Denizli, Acipayam, Southwest Anatolia, Turkey, in July 2001. Voucher specimens (HUEF 01006) have been deposited at the herbarium of the Department of the Pharma- 
cognosy, Faculty of Pharmacy, Hacettepe University, Ankara, Turkey.

\section{Extraction and isolation}

The air-dried and powdered aerial parts of $G$. $d u$ mulosa $(170 \mathrm{~g})$ were extracted twice with $\mathrm{MeOH}$ $(2 \times 800 \mathrm{ml})$ at $45^{\circ} \mathrm{C}$. The combined methanolic extracts were evaporated to dryness in vacuo $(52.5 \mathrm{~g}$, yield $30 \%)$. The crude extract was dissolved in $\mathrm{H}_{2} \mathrm{O}$ and partitioned against $\mathrm{CHCl}_{3}$. An aliquot $(34 \mathrm{~g})$ of the lyophilized $\mathrm{H}_{2} \mathrm{O}$ phase $(40.1 \mathrm{~g})$ was fractionated over LiChroprep C-18 (VLC). Employment of $\mathrm{H}_{2} \mathrm{O}, \mathrm{H}_{2} \mathrm{O}-\mathrm{MeOH}$ mixtures with increasing amount of $\mathrm{MeOH}$ in $\mathrm{H}_{2} \mathrm{O}$ $(5-80 \%, \mathrm{MeOH})$ and $\mathrm{MeOH}$ afforded nine main fractions, A-I. Fraction B (7.9 g) was subjected to $\mathrm{SiO}_{2}-\mathrm{VLC}$ using a $\mathrm{CHCl}_{3}-\mathrm{MeOH}-\mathrm{H}_{2} \mathrm{O}$ gradient system (90:10:1 to 50:50:5 v/v/v) to yield four fractions, $\mathrm{B}_{1}-\mathrm{B}_{4}$. Fraction $\mathrm{B}_{2}(323 \mathrm{mg})$ was rechromatographed on silica $\mathrm{CC}\left(\mathrm{CHCl}_{3}-\mathrm{MeOH}-\mathrm{H}_{2} \mathrm{O}\right.$, 90:10:1 to $80: 20: 1 \mathrm{v} / \mathrm{v} / \mathrm{v})$ to give two fractions, $\mathrm{B}_{2 \mathrm{a}}$ and $\mathrm{B}_{2 \mathrm{~b}}$. Purification of fr. $\mathrm{B}_{2 \mathrm{a}}(87 \mathrm{mg})$ by Sephadex LH-20 CC using MeOH furnished demethoxycentaureidin $7-O-\beta$-D-glucopyranoside $\quad(3 \mathrm{mg})$. Fraction $\mathrm{B}_{4}(2.5 \mathrm{~g})$ was subjected to $\mathrm{C}_{18}$ medium pressure liquid chromatography $\left(\mathrm{C}_{18}\right.$-MPLC) employing increasing amount of $\mathrm{MeOH}$ in $\mathrm{H}_{2} \mathrm{O}(0-$ $40 \%)$ to afford catalpol $(6,46 \mathrm{mg})$, aucubin (4, $114 \mathrm{mg})$, decaffeoylverbascoside $(7 \mathrm{mg})$ and a crude fraction of deacetylalpinoside. The latter was further applied to a Sephadex LH-20 column using $\mathrm{MeOH}$ as eluent to give pure 9 (3 mg). Fraction D ( $2.950 \mathrm{~g})$ was similarly separated by $\mathrm{C}_{18}$-MPLC using 10 to $60 \% \mathrm{MeOH}$ in $\mathrm{H}_{2} \mathrm{O}$ as eluents to give five fractions, $\mathrm{D}_{1}-\mathrm{D}_{5}$. Fraction $\mathrm{D}_{2}$ (449 mg) was rechromatographed on silica CC $\left(\mathrm{CHCl}_{3}-\mathrm{MeOH}-\mathrm{H}_{2} \mathrm{O}, 80: 20: 1\right.$ to $\left.70: 30: 3 \mathrm{v} / \mathrm{v} / \mathrm{v}\right)$ to obtain 10- $O$-benzoylcatalpol $(7,11 \mathrm{mg})$ and an additional fraction $\mathrm{D}_{2 \mathrm{~b}}$. Purification of fr. $\mathrm{D}_{2 \mathrm{~b}}$ (200 mg) by $\mathrm{C}_{18}$-MPLC (15-35\% $\left.\mathrm{MeOH}\right)$ furnished alpinoside (8, $7 \mathrm{mg})$ and verbascoside $(142 \mathrm{mg})$. Fraction $\mathrm{D}_{3}(281 \mathrm{mg})$ was applied to a $\mathrm{Si}$ gel column eluting with $\mathrm{CHCl}_{3}-\mathrm{MeOH}-\mathrm{H}_{2} \mathrm{O}$ mixture $(70: 30: 3 \mathrm{v} / \mathrm{v} / \mathrm{v})$ to give dumuloside (2, $28 \mathrm{mg}$ ) and additional fraction $\mathrm{D}_{3 \mathrm{~b}}$. Repeated chromatography of fr. $\mathrm{D}_{3 \mathrm{~b}}(64 \mathrm{mg})$ on a Sephadex LH-20 column using $\mathrm{MeOH}$ as eluent yielded nepetin 7-O- $\beta$-D-glucopyranoside $(4 \mathrm{mg})$. Fraction $\mathrm{D}_{5}$ (117 mg) was purified by silica CC using gradient
$\mathrm{CHCl}_{3}-\mathrm{MeOH}-\mathrm{H}_{2} \mathrm{O}$ mixtures (85:15:0 to 70:30:3 $\mathrm{v} / \mathrm{v} / \mathrm{v})$ to obtain $10-O$-benzoylglobularigenin (1, $6 \mathrm{mg}$ ) and melampyroside $(\mathbf{5}, 59 \mathrm{mg})$. Fraction $\mathrm{F}$ (4.610 g) was likewise subjected to $\mathrm{C}_{18}$-MPLC using stepwise gradients of $\mathrm{MeOH}(20-60 \%)$ in $\mathrm{H}_{2} \mathrm{O}$ to yield five main fractions, $\mathrm{F}_{1}-\mathrm{F}_{5}$. Repeated chromatography of fraction $\mathrm{F}_{2}(875 \mathrm{mg})$ using the similar method ( $\mathrm{C}_{18}$-MPLC; 20-55\% $\left.\mathrm{MeOH}\right)$ gave verbascoside $(38 \mathrm{mg})$ and fractions $\mathrm{F}_{2 \mathrm{~b}}-\mathrm{F}_{2 \mathrm{~d}}$. Fraction $\mathrm{F}_{2 \mathrm{c}}(158 \mathrm{mg})$ was rechromatographed over $\mathrm{Si}$ gel eluting with $\mathrm{CHCl}_{3}-\mathrm{MeOH}-\mathrm{H}_{2} \mathrm{O}$ (80:20:2 to $70: 30: 3 \mathrm{v} / \mathrm{v} / \mathrm{v})$ to give leucosceptoside $\mathrm{A}$ $(10 \mathrm{mg})$ along with impure davisioside. The latter was further applied to a Si gel column employing EtOAc-MeOH- $\mathrm{H}_{2} \mathrm{O}(100: 8: 4 \mathrm{v} / \mathrm{v} / \mathrm{v})$ mixture to afford pure davisioside $(\mathbf{3}, 29 \mathrm{mg})$. Fraction $\mathrm{H}$ $(1.380 \mathrm{~g})$ was also subjected to $\mathrm{C}_{18}$-MPLC using stepwise gradients of $\mathrm{MeOH}$ in $\mathrm{H}_{2} \mathrm{O}(35-75 \%$ $\mathrm{MeOH})$ to give melampyroside $(\mathbf{5}, 24 \mathrm{mg}$ ) and three main fractions, $\mathrm{H}_{2}-\mathrm{H}_{4}$. Fraction $\mathrm{H}_{4}(93 \mathrm{mg})$ was also purified by Sephadex LH-20 CC employing $\mathrm{MeOH}$ as eluent to obtain pectolinarigenin 7$O$ - $\beta$-D-glucopyranoside $(9 \mathrm{mg})$.

10-O-Benzoylglobularigenin (1): Amorphous powder; $[\alpha]_{\mathrm{D}}^{20}-41^{\circ}(c=0.1, \mathrm{MeOH})$; HR-MALDIMS $m / z: 313.1041[\mathrm{M}+\mathrm{Na}]^{+}$; UV $\lambda_{\max }(\mathrm{MeOH}$, $\mathrm{nm}): 207$ (sh), 229, 275; IR $v_{\max }\left(\mathrm{KBr}, \mathrm{cm}^{-1}\right) 3346$ $(\mathrm{OH}), 1722$ (ester $\mathrm{C}=\mathrm{O}), 1457$ (aromatic ring); ${ }^{1} \mathrm{H}-\mathrm{NMR}$ (300 MHz, CD $\mathrm{OD}$ ): Table I; ${ }^{13} \mathrm{C}-\mathrm{NMR}$ $\left(\mathrm{CD}_{3} \mathrm{OD}, 75.5 \mathrm{MHz}\right)$ : Table I.

Dumuloside (2): Amorphous powder; $[\alpha]_{\mathrm{D}}^{20}-70^{\circ}$ $(c=0.1, \mathrm{MeOH}) ;$ HR-MALDIMS $m / z: 473.1416$ $[\mathrm{M}+\mathrm{Na}]^{+} ; \mathrm{UV} \lambda_{\max }(\mathrm{MeOH}, \mathrm{nm}): 207,233,273$; IR $v_{\max }\left(\mathrm{KBr}, \mathrm{cm}^{-1}\right) 3460(\mathrm{OH}), 1718($ ester $\mathrm{C}=\mathrm{O})$, $1654(\mathrm{C}=\mathrm{C}-\mathrm{O}), 1603,1559,1542,1508$ (aromatic ring); ${ }^{1} \mathrm{H}-\mathrm{NMR}$ (300 MHz, $\mathrm{CD}_{3} \mathrm{OD}$ ): Table II; ${ }^{13} \mathrm{C}-\mathrm{NMR}\left(\mathrm{CD}_{3} \mathrm{OD}, 75.5 \mathrm{MHz}\right)$ : Table II.

\section{Results and Discussion}

Compound $\mathbf{1}$ was obtained as an amorphous powder, $[\alpha]_{\mathrm{D}}-41$ ( $c$ $\left.0.1, \mathrm{MeOH}\right)$. The molecular formula was determined as $\mathrm{C}_{16} \mathrm{H}_{18} \mathrm{O}_{5}$ by using a combination of positive-ion HR-MALDIMS $(\mathrm{m} / \mathrm{z}$ 313.1041, $[\mathrm{M}+\mathrm{Na}]^{+}$) and ${ }^{13} \mathrm{C}$ NMR data (see Table I). The UV spectrum exhibited maxima at 207 (sh), 229 and $275 \mathrm{~nm}$. The IR spectrum showed absorption bands for hydroxyl $\left(3346 \mathrm{~cm}^{-1}\right)$, ester carbonyl $\left(1722 \mathrm{~cm}^{-1}\right)$ and aromatic $\left(1457 \mathrm{~cm}^{-1}\right)$ functionalities. The ${ }^{1} \mathrm{H}$ NMR spectrum (see Table 


\begin{tabular}{rlrll}
\hline $\mathrm{C} / \mathrm{H}$ & & $\delta_{\mathrm{C}} \mathrm{ppm}$ & $\delta_{\mathrm{H}} \mathrm{ppm}, J[\mathrm{~Hz}]$ & $\mathrm{HMBC}(\mathrm{H} \rightarrow \mathrm{C})$ \\
\hline 1 & $\mathrm{CH}$ & 100.0 & $4.43 \mathrm{~d}(7.9)$ & $\mathrm{C}-3, \mathrm{C}-8, \mathrm{C}-9$ \\
$3 \alpha$ & $\mathrm{CH}_{2}$ & 63.0 & $3.63 \mathrm{~m}$ & $\mathrm{C}-1, \mathrm{C}$ \\
$3 \beta$ & & & $3.93 \mathrm{~m}$ & $\mathrm{C}-1, \mathrm{C}-5$ \\
$4 \alpha$ & $\mathrm{CH}_{2}$ & 25.0 & $1.83 \mathrm{~m}$ & $\mathrm{C}-3, \mathrm{C}-5, \mathrm{C}-6$ \\
$4 \beta$ & & & $1.76 \mathrm{~m}$ & $\mathrm{C}-3, \mathrm{C}-5, \mathrm{C}-6$ \\
5 & $\mathrm{CH}$ & 48.3 & $2.37 \mathrm{~m}$ & $\mathrm{C}-1, \mathrm{C}-3, \mathrm{C}-6, \mathrm{C}-9$ \\
6 & $\mathrm{CH}$ & 78.2 & $4.69 \mathrm{br} \mathrm{d}(7.9)$ & $\mathrm{C}-4, \mathrm{C}-7, \mathrm{C}-8$ \\
7 & $\mathrm{CH}$ & 132.5 & $5.86 \mathrm{br} \mathrm{s}$ & $\mathrm{C}-5, \mathrm{C}-8, \mathrm{C}-9, \mathrm{C}-10$ \\
8 & $\mathrm{C}$ & 144.0 & & \\
9 & $\mathrm{CH}$ & 50.9 & $2.58 \mathrm{t}(7.5)$ & $\mathrm{C}-1, \mathrm{C}-5, \mathrm{C}-6, \mathrm{C}-7, \mathrm{C}-8$ \\
10 & $\mathrm{CH} 2$ & 64.2 & $5.01 \mathrm{~d}(14.8)$ & $\mathrm{C}-7, \mathrm{C}-8, \mathrm{C}-9, \mathrm{C}=\mathrm{O}$ \\
& & & $4.91 \mathrm{~d}(14.8)$ & $\mathrm{C}-7, \mathrm{C}-8, \mathrm{C}=\mathrm{O}$ \\
$1^{\prime}$ & $\mathrm{C}$ & 131.3 & & \\
$2^{\prime}$ & $\mathrm{CH}$ & 130.6 & $8.06 \mathrm{dd}(7.4,1.3)$ & $\mathrm{C}=\mathrm{O}, \mathrm{C}-4^{\prime}$ \\
$3^{\prime}$ & $\mathrm{CH}$ & 129.7 & $7.50 \mathrm{t}(7.4)$ & $\mathrm{C}-1^{\prime}, \mathrm{C}-5^{\prime}$ \\
$4^{\prime}$ & $\mathrm{CH}$ & 134.4 & $7.63 \mathrm{~m}$ & $\mathrm{C}-2^{\prime}, \mathrm{C}-6^{\prime}$ \\
$5^{\prime}$ & $\mathrm{CH}$ & 129.7 & $7.50 \mathrm{t}(7.4)$ & $\mathrm{C}-1^{\prime}, \mathrm{C}-3^{\prime}$ \\
$6^{\prime}$ & $\mathrm{CH}$ & 130.6 & $8.06 \mathrm{dd}(7.4,1.3)$ & $\mathrm{C}=\mathrm{O}, \mathrm{C}-4^{\prime}$ \\
$\mathrm{C}^{\prime}=\mathrm{O}$ & $\mathrm{C}$ & 167.2 & & \\
\hline
\end{tabular}

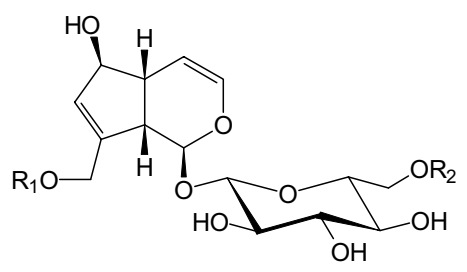

$2 \mathrm{R}_{1}=\mathrm{H}, \mathrm{R}_{2}=$ benzoyl $4 \mathrm{R}_{1}=\mathrm{R}_{2}=\mathrm{H}$

$5 \mathrm{R}_{1}=$ benzoyl, $\mathrm{R}_{2}=\mathrm{H}$
Table I. The ${ }^{13} \mathrm{C}$ and ${ }^{1} \mathrm{H}$ NMR spectroscopic data and HMBC correlations for $1\left(\mathrm{CD}_{3} \mathrm{OD},{ }^{13} \mathrm{C}\right.$ : $75.5 \mathrm{MHz} ;{ }^{1} \mathrm{H}$ : $300 \mathrm{MHz})^{*}$.
* All proton and carbon assignments are based on 2D NMR (DQF-COSY, HSQC, HMBC and ROESY).

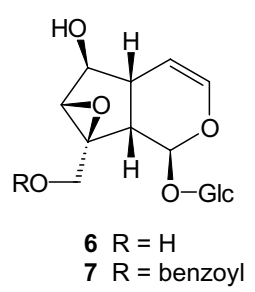

I) contained signals due to an olefinic proton $\left(\delta_{\mathrm{H}} 5.86\right)$, an acetal proton $\left(\delta_{\mathrm{H}} 4.43\right)$, an oxygenated methine proton $\left(\delta_{\mathrm{H}} 4.69\right)$, two oxymethylenes $\left(\delta_{\mathrm{H}} 3.93\right.$ and $3.63 ; \delta_{\mathrm{H}} 5.01$ and 4.91$)$, two methines $\left(\delta_{\mathrm{H}} 2.58,2.37\right)$ and two diastereopic protons of a methylene $\left(\delta_{\mathrm{H}} 1.83,1.76\right)$. Additional aromatic proton signals at $\delta_{\mathrm{H}} 8.06(2 \mathrm{H}), 7.63(1 \mathrm{H})$ and 7.50 $(2 \mathrm{H})$ together with the corresponding carbon resonances, supported the presence of a benzoyl moiety. The ${ }^{13} \mathrm{C}$ NMR spectrum of $\mathbf{1}$ displayed 16 signals, seven of which were ascribed to a benzoic acid. All the remaining carbon resonances indi- cated that $\mathbf{1}$ has an iridoid skeleton composed of a cyclopentanopyran ring system with nine carbon atoms. The complete assignments of all proton and carbon resonances were based on DQF-COSY, HSQC and HMBC (see Table I) experiments. Thus, the established NMR data of $\mathbf{1}$ were similar to those of davisoside (Calis et al., 2002a), which was previously isolated from $G$. davisiana, except the absence of any sugar signal in the NMR spectra of compound $\mathbf{1}$. In the HMBC spectrum the expected long-range couplings for the iridoid skeleton were observed. The downfield shifts for 


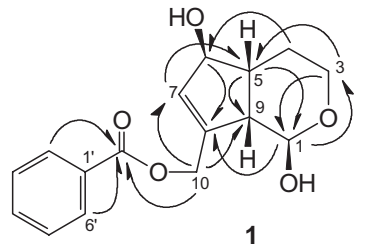

1

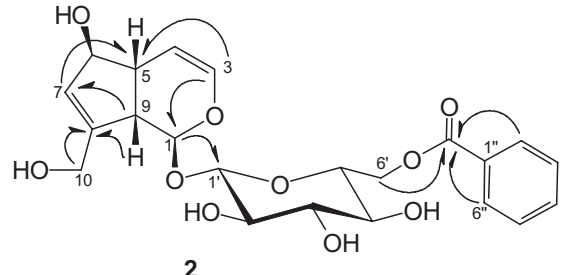

2
Fig. 2. Selected HMBC Correlations for $\mathbf{1}$ and $\mathbf{2}$.
$\mathrm{H}_{2}-10\left(\delta_{\mathrm{H}} 5.01\right.$ and 4.91$)$ signals and the significant ${ }^{1} \mathrm{H}-{ }^{13} \mathrm{C}$ HMBC cross-peak between $\mathrm{H}_{2}-10$ and the carbonyl carbon $\left(\delta_{\mathrm{C}} 167.2\right)$ of the benzoic acid indicated the site of acylation. To prove the relative stereochemistry of the chiral centers in $\mathbf{1}$, a $2 \mathrm{D}$ ROESY experiment was performed. ROe crosspeaks of significant intensity between $\mathrm{H}-9 / \mathrm{H}-5$ and $\mathrm{H}-9 / \mathrm{H}-4 \beta$ indicated that these protons lie on the same side $(\beta)$ of the molecule. Contrary, prominent ROe correlations were observed between H-1/H-3 $\alpha, \mathrm{H}-1 / \mathrm{H}-6$ and H-4 $\alpha / \mathrm{H}-6$. Therefore, the secondary alcohol functions at C-1 and C-6 had to be in the $\beta$ position. These correlations also confirmed the cis fusion of the cyclopentan and pyran rings as expected. Consequently, the structure of compound $\mathbf{1}$ was determined as a non-glycosidic iridoid with a saturated $\Delta^{3,4}$. We propose the trivial name $10-O$-benzoylglobularigenin for this compound.
Compound 2 was obtained as an amorphous powder, $[\alpha]_{\mathrm{D}}-70(c$ 0.1, $\mathrm{MeOH})$. The molecular formula was determined to be $\mathrm{C}_{22} \mathrm{H}_{26} \mathrm{O}_{10}$ by positive-ion HR-MALDIMS $\left(\mathrm{m} / \mathrm{z}\right.$ 473.1416, $\left.[\mathrm{M}+\mathrm{Na}]^{+}\right)$ and ${ }^{13} \mathrm{C}$ NMR data (see Table II). Compound 2 exhibited UV maxima at 207, 233 and $273 \mathrm{~nm}$. The IR spectrum showed absorption bands at 3460 (br $\mathrm{OH}), 1718$ (ester) 1654 ( $\mathrm{C}=\mathrm{C}-\mathrm{O})$ and 1603, 1559, $1542,1508 \mathrm{~cm}^{-1}$ (aromatic ring). Analysis of the ${ }^{1} \mathrm{H}$ NMR spectrum (see Table II) revealed 2 to be an iridoid glycoside with an acyl moiety. The olefinic proton signals at $\delta_{\mathrm{H}} 5.63(\mathrm{H}-7), 6.30(\mathrm{H}-3)$, $5.08(\mathrm{H}-4)$ and oxymethine signal at $\delta_{\mathrm{H}} 4.25(\mathrm{H}-6)$ indicated that the structure of the aglycone is like that of aucubin. The anomeric proton resonance at $\delta_{\mathrm{H}} 4.70(\mathrm{~d}, J=7.8 \mathrm{~Hz})$ together with the signals in the region 3.26-4.62 suggested the presence of a $\beta$-glucopyranosyl unit. Additional aromatic proton signals at $\delta_{\mathrm{H}} 8.00(2 \mathrm{H}), 7.61(1 \mathrm{H})$ and 7.48

\begin{tabular}{|c|c|c|c|c|}
\hline \multicolumn{2}{|l|}{$\mathrm{C} / \mathrm{H}$} & \multirow{2}{*}{$\frac{\delta_{\mathrm{C}} \mathrm{ppm}}{98.4}$} & \multirow{2}{*}{$\frac{\delta_{\mathrm{H}} \mathrm{ppm}, J[\mathrm{~Hz}]}{4.73 \mathrm{~d}(7.7)}$} & \multirow{2}{*}{$\begin{array}{l}\mathrm{HMBC}(\mathrm{H} \rightarrow \mathrm{C}) \\
\mathrm{C}-1^{\prime}\end{array}$} \\
\hline 1 & $\mathrm{CH}$ & & & \\
\hline 3 & $\mathrm{CH}$ & 141.7 & $6.30 \mathrm{dd}(6.1,1.8)$ & C-1, C-4, C-5 \\
\hline 4 & $\mathrm{CH}$ & 105.6 & $5.08 \mathrm{dd}(6.1,4.0)$ & $\mathrm{C}-3$ \\
\hline 5 & $\mathrm{CH}$ & 46.7 & $2.59 \mathrm{~m}$ & \\
\hline 6 & $\mathrm{CH}$ & 83.0 & $4.25^{\dagger}$ & \\
\hline 7 & $\mathrm{CH}$ & 130.7 & $5.63 \mathrm{~d}(1.0)$ & C-5, C-9 \\
\hline 8 & $\mathrm{C}$ & 147.7 & & \\
\hline 9 & $\mathrm{CH}$ & 47.7 & 2.84 t (7.7) & C-1, C-7, C-8 \\
\hline \multirow[t]{2}{*}{10} & $\mathrm{CH}_{2}$ & 61.5 & $4.23 \mathrm{~d}(15.4)$ & \\
\hline & & & $4.11 \mathrm{~d}(15.4)$ & C-8 \\
\hline $1^{\prime}$ & $\mathrm{CH}$ & 100.1 & $4.70 \mathrm{~d}(7.8)$ & $\mathrm{C}-1$ \\
\hline $2^{\prime}$ & $\mathrm{CH}$ & 74.8 & $3.26 \mathrm{dd}(7.8,8.6)$ & C-3' \\
\hline $3^{\prime}$ & $\mathrm{CH}$ & 77.8 & $3.39^{\dagger}$ & C- $4^{\prime}$ \\
\hline $4^{\prime}$ & $\mathrm{CH}$ & 72.0 & $3.38^{\dagger}$ & C- $3^{\prime}$ \\
\hline $5^{\prime}$ & $\mathrm{CH}$ & 75.6 & $3.60 \mathrm{~m}$ & C- $3^{\prime}, C-4^{\prime}$ \\
\hline \multirow[t]{2}{*}{$6^{\prime}$} & $\mathrm{CH}_{2}$ & 65.1 & $4.62 \mathrm{dd}(11.8,2.3)$ & \\
\hline & & & $4.47 \mathrm{dd}(11.8,6.8)$ & $\mathrm{C}=\mathrm{O}$ \\
\hline $\begin{array}{l}1^{\prime \prime} \\
2^{\prime \prime}\end{array}$ & $\mathrm{C}$ & 131.3 & & \\
\hline $2^{\prime \prime}$ & $\mathrm{CH}$ & 130.6 & $8.00 \mathrm{dd}(7.5,1.3)$ & $\mathrm{C}=\mathrm{O}, \mathrm{C}-4^{\prime \prime}, \mathrm{C}-6^{\prime \prime}$ \\
\hline $3^{\prime \prime}$ & $\mathrm{CH}$ & 129.6 & $7.48 \mathrm{t}(7.5)$ & C-1", C-5" \\
\hline $4^{\prime \prime}$ & $\mathrm{CH}$ & 134.4 & $7.61 \mathrm{~m}$ & $\mathrm{C}-2^{\prime \prime}, \mathrm{C}-6^{\prime \prime}$ \\
\hline $5^{\prime \prime}$ & $\mathrm{CH}$ & 129.6 & 7.48 t (7.5) & C-1", C-3" \\
\hline $6^{\prime \prime}$ & $\mathrm{CH}$ & 130.6 & $8.00 \mathrm{dd}(7.5,1.3)$ & $\mathrm{C}=\mathrm{O}, \mathrm{C}-2^{\prime \prime}, \mathrm{C}-4^{\prime \prime}$ \\
\hline $\mathrm{C}=\mathrm{O}$ & $\mathrm{C}$ & 167.8 & & \\
\hline
\end{tabular}

Table II. The ${ }^{13} \mathrm{C}$ and ${ }^{1} \mathrm{H}$ NMR spectroscopic data and HMBC correlations for $2\left(\mathrm{CD}_{3} \mathrm{OD},{ }^{13} \mathrm{C}\right.$ : $75.5 \mathrm{MHz} ;{ }^{1} \mathrm{H}$ : $300 \mathrm{MHz})^{*}$.

* All proton and carbon assignments were based on 2D NMR (DQFCOSY, HSQC and HMBC). † Signal patterns are unclear due to overlapping. 
$(2 \mathrm{H})$ and the corresponding carbon resonances were typical of a benzoyl moiety. The complete assignments of all proton and carbon resonances were based on the DQF-COSY, HSQC and HMBC (see Table II) experiments. Thus, compound 2 was established as benzoyl derivative of aucubin. The proton signals assigned to $\mathrm{H}_{2}-6^{\prime}$ $\left(\delta_{\mathrm{H}} 4.62\right.$ and 4.47$)$ of the glucose unit were found to be shifted downfield due to acylation. The HMBC correlations between H- $6^{\prime}\left(\delta_{\mathrm{H}} 4.47\right)$ of the glucose and the carbonyl carbon $\left(\delta_{\mathrm{C}} 167.8\right)$ of the benzoic acid suggested C- 6 ' to be site of benzoylation. Consequently, the structure of compound $\mathbf{2}$ was determined as $6^{\prime}$ - $O$-benzoylaucubin. For this new compound we propose the trivial name dumuloside.

Besides these new compounds, seven known iridoid glucosides, davisioside (3) (Calis et al., 2002a), aucubin (4) (Bianco et al., 1983), melampyroside (5) (Chaudhuri and Sticher, 1980), catalpol (6) (Chaudhuri and Sticher, 1981), 10-O-benzoylcatalpol (7) (Foderaro and Stermitz, 1992), alpinoside (8) (Jensen et al., 1996), deacetylalpinoside (= arborescosidic acid) (9) (Calis et al., 2001; Ronsted et al., 2000), three known phenylethanoid glycosides, verbascoside (Sticher and Lahloub, 1982), decaffeoylverbascoside (Burger et al., 1987), leucosceptoside A (Calis et al., 1988) and three flavone glucosides, pectolinarigenin $7-O-\beta-\mathrm{D}-\mathrm{glu}-$

Agrawal P. K., Thakur R. S., and Bansal M. C. (1989), In: Carbon-13 NMR of flavonoids (Agrawal P. K., ed). Elsevier Sciences Publishers B. V., Amsterdam, pp. $95-173$.

Baytop T. (1984), Therapy with medicinal plants (past and present). Istanbul University Publications, Istanbul, No. 3255, pp. 419.

Bianco A., Passacantilli P., Polidori G., Nicoletti M., and Messana I. (1983), NMR spectroscopy of epimeric pairs of glucosidic iridoids from Rubiaceae. Gazz. Chim. Ital. 113, 829-834.

Burger J. F. W., Brandt E. V., and Ferreira D. (1987), Iridoid and phenolic glycosides from Harpagophytum procumbens. Phytochemistry 26, 1453-1457.

Calis I., Saracoglu I., Kitagawa S., and Nishibe S. (1988), Phenylpropanoid glycosides isolated from Rhynchocorys stricta (Scrophulariaceae). Doga Tu J. Med. Pharm. 12, 234-238.

Calis I., Kirmizibekmez H., Rüegger H., and Sticher O. (1999), Phenylethanoid glycosides from Globularia trichosantha. J. Nat. Prod. 62, 1165-1168. copyranoside (Merfort, 1988), nepetin 7-O- $\beta$-Dglucopyranoside (Agrawal, 1989), demethoxycentaureidin 7-O- $\beta$-D-glucopyranoside (Yuldashev et al., 1996) were also isolated and identified by comparison of their spectral data with published values.

10-O-benzoylglobularigenin (1), and davisioside (3) represent a rare iridoid skeleton lacking the double bond between C-3 and C-4. 10-O-benzoylglobularigenin (1) is also the first non-glycosidic iridoid isolated from the genus Globularia. Among the isolated compouds, 8,9-unsaturated iridoids like alpinoside (8) and deacetylalpinoside (9) are very rare. These compounds have only been found in some species of Veronica and Plantago before. So these compounds may play an important role for the relationships between these three genera.

\section{Acknowledgment}

The authors thank Prof. Dr. Hayri Duman, Gazi University, Ankara, for authentification of the plant material; Dr. Engelbert Zass, Institute of Organic Chemistry, ETH Zurich, for performing computer-based literature searches; Dr. Walter Amrein and Mr. Rolf Haefliger Institute of Organic Chemistry, ETH Zurich for recording all mass spectra.

Calis I., Kirmizibekmez H., and Sticher O. (2001), Iridoid glycosides from Globularia trichosantha. J. Nat. Prod. 64, 60-64.

Calis I., Kirmizibekmez H., Tasdemir D., and Ireland C. M. (2002a), Iridoid glycosides from Globularia davisiana. Chem. Pharm. Bull. 50, 678-680.

Calis I., Kirmizibekmez H., Tasdemir D., Sticher O., and Ireland C. M. (2002b), Sugar esters from Globularia orientalis. Z. Naturforsch. 57 c, 591-596.

Chaudhuri R. K., and Sticher O. (1980), Globularifolin, a new acyl iridoid glucoside from Globularia cordifolia. Helv. Chim. Acta 63, 117-120.

Chaudhuri R. K., and Sticher O. (1981), New iridoid glycosides and a lignan diglucoside from Globularia alypum L. Helv. Chim. Acta 64, 3-15.

Duman H. (2001), A new species of Globularia L. (Globulariaceae) from South Anatolia. Bot. J. Linn. Soc. 137, 425-428.

Edmondson J. R. (1982), In: Flora of Turkey and East Aegean Islands (Davis P. H., ed). University Press. Edinburgh, Vol. 7, pp. 27-31. 
Foderaro T. A., and Stermitz F. R. (1992), Iridoid glycosides from Penstemon species: A C-5, C-9 trans iridoid and C-8 epimeric pairs. Phytochemistry 31, 41914195.

Jensen S. R., Olsen C. E., Rahn K., and Rasmussen J. H. (1996), Iridoid glucosides in Plantago alpina and $P$. altissima. Phytochemistry 42, 1633-1636.

Merfort I. (1988), Acetylated and other flavonoid glycosides from Arnica chamissonis. Phytochemistry 27, $3281-3284$

Ronsted N., Göbel E., Franzyk H., Jensen S. R., and Olsen C. E. (2000), Chemotaxonomy of Plantago. Iri- doid glucosides and caffeoyl phenylethanoid glycosides. Phytochemistry 55, 337-348.

Sezik E., Tabata M., Yesilada E., Honda G., Goto K., and Ikeshiro Y. (1991), Traditional medicine in Turkey I. Folk medicine in northeast Anatolia. J. Ethnopharm. 35, 191-196.

Sticher O., and Lahloub M. F. (1982), Phenolic glycosides from Paulownia tomentosa bark. Planta Med. 46, 145-148.

Yuldashev M. P., Batirov E. Kh., and Malikov, V. M. (1996), Flavonoids of the epigeal part of Kickxia elatine. Khim. Prir. Soedin. 1, 38-41. 